\title{
Critical Analysis of Adoption Pattern and Problems of Chilli Growers in Tenant Farming
}

\author{
K. Kiranmayi ${ }^{1 *}$ and B. Vijayabhinandana ${ }^{2}$ \\ ${ }^{1}$ KVK, Amadalavalasa, Srikakulam (Dt.), India \\ ${ }^{2}$ ANGRAU, Guntur, A.P., India \\ *Corresponding author
}

\begin{tabular}{|l|}
\hline K e y w o r d s \\
Chilli, Adoption, \\
Tenant farmers, \\
Package of \\
practices
\end{tabular}

\section{A B S T R A C T}

The study was taken up with the main objective of identifying and analyzing the adoption of package of practices by the Chilli farmers as recommended by the scientists of ANGRAU. It was conducted in 2013 with a sample of Sixty (60) tenant farmers in the Guntur district of Andhra Pradesh. Cent per cent of the respondents fell in the category of fully adopted with respect to time of harvest. 86.67 per cent of the respondents fully adopted recommended doses of fertilizers; while the remaining 13.33 per cent fell in the category of partially adopted. 81.67 per cent of the respondents fully adopted recommended dosage of pesticides, followed by partially adopted (18.33\%). 73.33 per cent of the respondents fully adopted the recommended number of irrigations; while the remaining 26.67 per cent fell in the category of partially adopted. 76.67 per cent of the respondents fully adopted the recommended varieties in chilli, followed by partially adopted $(23.33 \%)$. With respect to seed rate, 63.33 per cent of the respondents fell in the category of fully adopted, followed by partially adopted (36.67\%). A little more than half of the farmers had medium adoption $(61.67 \%)$ of recommended package of practices in chilli crop, followed by high (23.33\%) and low (15.00\%) adoption. Hiked land lease rents, lack of financial support from banks and payment of entire land lease rent in the form of cash were the major problems encountered by tenant farmers in tenant farming.

\section{Introduction}

The output and productivity of any farm land could be increased by following recommended package of practices, and chilli is not an exception. Chilli output could be increased if the farmers adopt the recommended package of practices. For increasing the level of adoption farmers need to be convinced about recent production technologies. The adoption of any technology depends on the individual development and acceptance of modern agricultural technology is the foremost important for increasing crop production. Agricultural technology is never completely accepted by the farmers in all respects, as such there always appears to be a gap between the recommended technology by the scientists and its modified form at the farmer's level. The technological gap is thus the major problem in the efforts of increasing agricultural production in the country. A need of the day is to reduce the technological gap between the agricultural technology recommended by the 
scientists and its acceptance by the farmers on their field. Hence a study was under taken to find out the adoption of recommended technologies by farmers in Chilli crop and the problems encountered by tenant farmers in tenant farming.

\section{Materials and Methods}

The study was conducted by using expost facto research design. For the purpose of study, sixty (60) tenant farmers growing Chilli were selected at random from Sattenapalli, Pedakurapadu and Veldurthy mandals in Guntur district of Andhra Pradesh. Data was collected during 2013 through structured interview schedule. The adoption schedule consisted of eleven (11) items related to package of practices in Chilli. The adoption of these items was measured on a three point continuum viz. fully adopted, partially adopted and not adopted.

For the purpose of study, adoption was operationalized as the adoption behaviour exhibited by the farmers towards the recommended package of practices in chilli crop. Fully adopted was operationally defined as complete adoption of a practice as recommended by the scientists of ANGRAU without any distortion. Partially adopted was operationally defined as the adoption of a practice to certain extent or partly and not completely. Not adopted was operationally defined as complete non-adoption of a practice by the farmers in Chilli cultivation.

The scoring pattern followed was 3 weights to fully adopted, 2 weights to partially adopted and 1 weight to not adopted. The maximum and minimum possible score of each respondent was 33 and 11, respectively. The total score of each respondent was also calculated by summing up the scores obtained for all the 11 items. The respondents were categorized into three categories of adoption namely; low, medium and high using mean and standard deviation. Frequency and percentages were calculated.

\section{Results and Discussion}

Content analysis of the adoption of recommended package of practices by the respondents in Chilli is presented in Table 1 and distribution of respondents based on adoption of package of practices is depicted in Table 2. Statement wise responses as shown in the table are discussed below.

\section{Soils}

Cent per cent of the tenant farmers practiced chilli cultivation in the recommended soils i.e. black and red soils. The selected sample of the study hail from the villages with black and red soils.

\section{Seed rate}

More than half of the tenant farmers fully adopted $(56.67 \%)$ the recommended seed rate, followed by fully adopted (43.33\%) and none of them were categorized under not adopted category. The probable reason might be to overcome the problem of less germination percentage and for gap filling.

\section{Seed treatment}

Nearly three-fourth of the respondents has not treated the seed $(73.33 \%)$, and the remaining partially adopted (26.67\%) seed treatment. None of them were categorized under not adopted categories. In most of the cases the farmers purchased the treated seed.

\section{Spacing}

Less than half of the tenant farmers fully adopted $(45.00 \%)$ the recommended spacing, followed by partially adopted (43.33\%) and 
not adopted (11.67\%). A few of the farmers adopted closer spacing than recommended as in the view that more population stand would give more profits.

\section{Varieties}

More than three-fourth of the tenant farmers fully adopted $(76.67 \%)$ the recommended varieties in chilli, followed by partially adopted (23.33\%) and none of them were categorized under not adopted category.

The partially adopted respondents preferred the varieties from private seed organisations.

\section{Fertilizers}

Majority of the tenant farmers fully adopted $(86.67 \%)$ the recommended dose of fertilizers, followed by partially adopted (13.33\%) and none of them were categorized under not adopted category. It was observed from the study area that a few farmers were opting to indiscriminate use of fertilizers with a misapprehension to achieve high profits.

\section{Irrigation}

Most of the tenant farmers fully adopted $(73.33 \%)$ the recommended number of irrigations, followed by partially adopted $(26.67 \%)$ and none of them were categorized under not adopted categories. The selected areas of the study has good irrigation potential and more over water as a natural resource is available at free of cost hence used it luxuriously and more than required.

\section{Pest control}

Majority of the tenant farmers fully adopted $(81.67 \%)$ the recommended dosage of pesticides, followed by partially adopted $(18.33 \%)$ and none of them were categorized under not adopted category.
The selected sample area has many pesticide dealers and shops. As a result any new pesticide released is first seen in these areas of Guntur and as and when released in the market these farmers apply in their fields in excess in anticipation of higher profits.

However a few owner farmers also practiced organic cultivation.

\section{Disease control}

More than half of the tenant farmers fully adopted $(78.33 \%)$ the recommended dosage of chemicals against diseases, followed by partially adopted (21.67\%) and none of them were categorized under not adopted category.

The same as in case of fertilizers could be accounted for disease control also.

\section{Harvesting}

Cent per cent of the tenant farmers harvest the produce at right maturity time

\section{Drying and storage}

Nearly half of the tenant farmers fully adopted $(43.34 \%)$ the recommended drying and storage methods, followed by not adopted $(33.33 \%)$ and partially adopted $(23.33 \%)$ the drying and storage methods.

Out of experience the farmers developed and practiced conventional methods of drying and storage of chilli produce.

Hence a few of the respondents were observed in not recommended category.

The scores on each recommended package of practice were summed up and the respondents were categorized into three categories of adoption behaviour namely low, medium and high as shown in Table 2. 
Table.1 Content analysis of adoption of package of practices in chilli cultivation

\begin{tabular}{|c|c|c|c|c|c|c|c|}
\hline \multirow[t]{3}{*}{ S. No. } & \multirow[t]{3}{*}{ Recommended practice } & \multicolumn{6}{|c|}{ Extent of adoption } \\
\hline & & \multicolumn{2}{|c|}{ FA } & \multicolumn{2}{|c|}{ PA } & \multicolumn{2}{|c|}{ NA } \\
\hline & & $\mathbf{F}$ & $\%$ & $\mathbf{F}$ & $\%$ & $\mathbf{F}$ & $\%$ \\
\hline 1. & $\begin{array}{l}\text { Soils: black soils, chalka soils, sandy loams } \\
\text { and red soils }\end{array}$ & 60 & 100.00 & - & - & - & - \\
\hline 2. & $\begin{array}{l}\text { Seed rate: Nursery- } 650 \mathrm{gm} / 40 \mathrm{~m}^{\wedge} 2 \\
\text { Direct sowing- } 6.25 \mathrm{~kg} / \mathrm{ha}\end{array}$ & 38 & 63.33 & 22 & 36.67 & - & - \\
\hline 3. & $\begin{array}{l}\text { Seed treatment: Imidacloprid @ } 8 \mathrm{~g} / \mathrm{kg} \text { seed } \\
\text { followed by } 3 \mathrm{gm} \text { captan } / \mathrm{kg} \text { seed (or) soil } \\
\text { application of Fipronil granules @ } 80 \mathrm{gm} / 40 \\
\text { sqm nursery followed by } 3 \mathrm{~g} \text { captan } / \mathrm{kg} \text { seed. }\end{array}$ & - & - & 16 & 26.67 & 44 & 73.33 \\
\hline 4. & $\begin{array}{l}\text { Spacing :Irrigated }-56 \mathrm{~cm} * 56 \mathrm{~cm} \text { or } \\
60 \mathrm{~cm} * 60 \mathrm{~cm}-\text { two seedlings/hill } \\
\text { Rainfed }-56 \mathrm{~cm} * 15 \mathrm{~cm}-\text { single seedling/hill }\end{array}$ & 27 & 45.00 & 26 & 43.33 & 7 & 11.67 \\
\hline 5. & $\begin{array}{l}\text { Varieties: G4, LCA-334, LCA-353, LCA } 235 \\
\text { \& LCA } 305 . \\
\text { Hybrid-Indan5 }\end{array}$ & 46 & 76.67 & 14 & 23.33 & - & - \\
\hline 6. & $\begin{array}{l}\text { Fertilizers : } \\
\text { Rainfed : } 80 \mathrm{~N}+40 \mathrm{P} 2 \mathrm{O} 5+50 \mathrm{~K} 2 \mathrm{O} \mathrm{kg} / \mathrm{ha} \\
\text { Irrigated : } 300 \mathrm{~N}+60 \mathrm{P} 2 \mathrm{O} 5+120 \mathrm{~K} 2 \mathrm{O}\end{array}$ & 52 & 86.67 & 8 & 13.33 & - & - \\
\hline 7. & Irrigation : $3-4$ irrigations & 44 & 73.33 & 16 & 26.67 & - & - \\
\hline 8 & $\begin{array}{l}\text { Pest control : } \\
\text {-Pod borer - thiodicarb @ } 1 \mathrm{gm} \text { or spinosad @ } \\
0.23 \mathrm{ml} \text { or acephate @ } 1.5 \mathrm{gm} \text { or chloripyriphos } \\
\text { @ } 2.5 \mathrm{ml} / \mathrm{L} \text { of water. } \\
\text { - Thrips - acephate } 1.5 \mathrm{gm} \text { or fipronil } 2 \mathrm{ml} \text { or } \\
\text { spinosad } 0.25 \mathrm{ml} \text { or chloripyriphos @ } 2.5 \mathrm{ml} / \mathrm{L} \\
\text { of water. } \\
\text {-Mites - dicophol } 5 \mathrm{ml} \text { or chloripyriphos } \\
2.5 \mathrm{ml} / \mathrm{L} \text { of water. }\end{array}$ & 49 & 81.67 & 11 & 18.33 & - & - \\
\hline
\end{tabular}




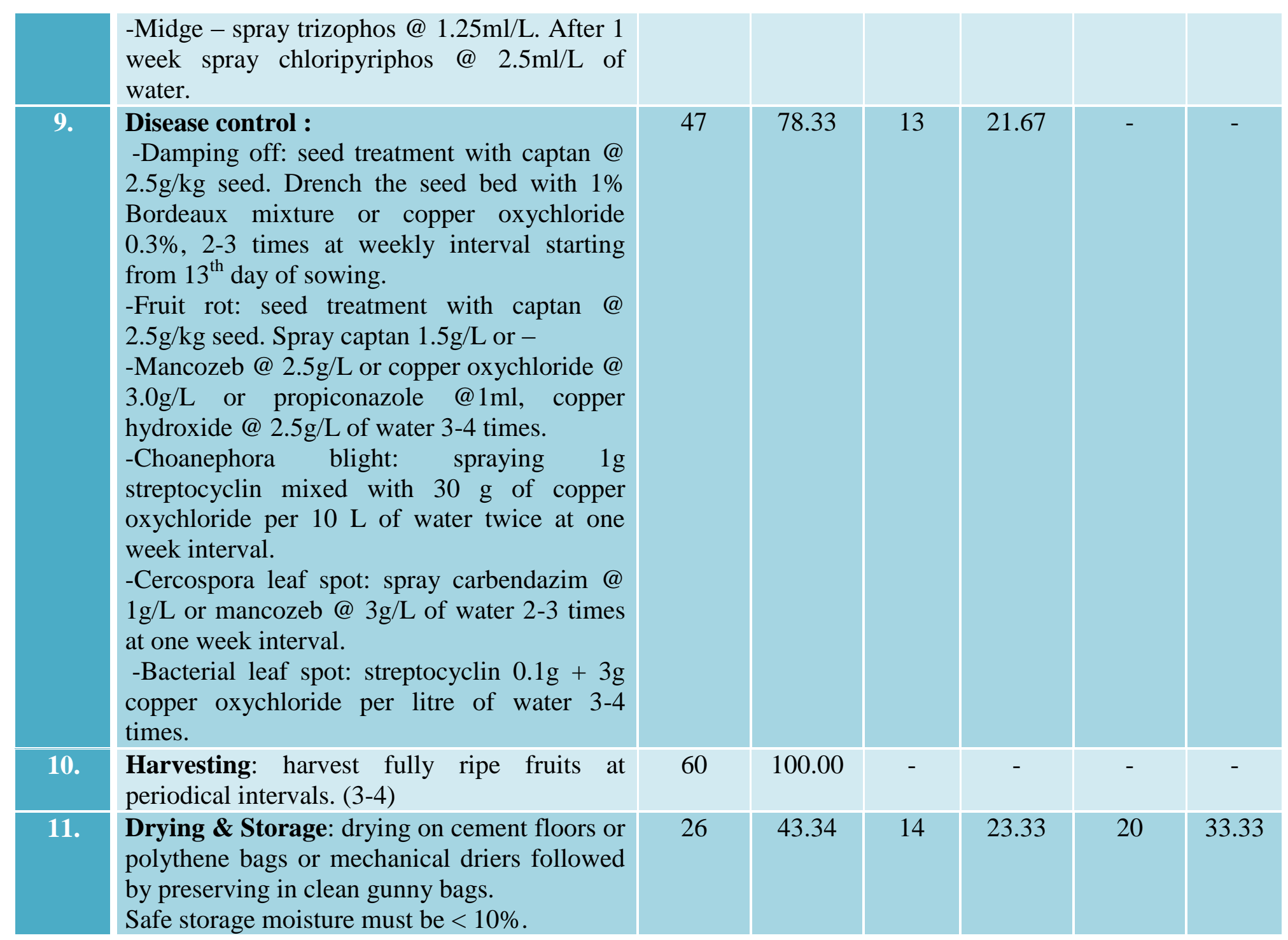

FA-Fully adopted, PA-Partially adopted, NA-Not adopted

F-Frequency, \%-Percentage 
Table.2 Distribution of respondents based on adoption of package of practices in Chilli

\begin{tabular}{|l|c|c|}
\hline \multicolumn{1}{|c|}{ Category } & \multicolumn{2}{|c|}{ Farmers $(\mathbf{N}=\mathbf{6 0})$} \\
\hline Low & F & $\%$ \\
\hline Medium & 9 & 15.00 \\
\hline High & 37 & 61.67 \\
\hline
\end{tabular}

$(\mathrm{N}=60)$

Table.3 Problems encountered by the tenant farmers in tenant farming

\begin{tabular}{|c|c|c|c|c|}
\hline & & \multicolumn{3}{|c|}{$(\mathrm{N}=60)$} \\
\hline S. No & Problems & $\mathbf{F}$ & $\%$ & Rank \\
\hline 1 & Land lease rents are hiked and more & 60 & 100.00 & I \\
\hline 2 & $\begin{array}{l}\text { Most of the land owners demand payment of land leased rent before the } \\
\text { commencement of the cropping season }\end{array}$ & 60 & 100.00 & I \\
\hline 3 & Lack of financial support from banks & 60 & 100.00 & I \\
\hline 4 & It is difficult to pay the entire land lease rent in the form of cash & 56 & 93.33 & II \\
\hline 5 & Money lenders are main source of credit lending money at high interest rates & 56 & 93.33 & II \\
\hline 6 & Tenancy tenures are mostly short term & 51 & 85.00 & III \\
\hline 7 & Developmental departments do not offer agricultural trainings for tenant farmers. & 48 & 80.00 & IV \\
\hline 8 & Input subsidy is not applicable for tenant farmers & 44 & 73.33 & V \\
\hline 9 & No fixed land lease rents & 41 & 68.33 & VI \\
\hline 10 & No vouchers are given for payment of lease rents for the land. & 40 & 66.67 & VII \\
\hline 11 & Lease contracts are verbal and no written agreements are made. & 36 & 60.00 & VIII \\
\hline 12 & Crop insurance is not applicable for tenant farmers & 32 & 53.33 & IX \\
\hline 13 & Weather insurance is not applicable for tenant farmers & 26 & 43.33 & $\mathrm{X}$ \\
\hline
\end{tabular}

Note: Responses are inclusive

Table.4 Suggestions from tenant farmers to overcome the problems in tenant farming

\begin{tabular}{|c|l|c|c|c|}
\hline S. No & \multicolumn{1}{|c}{ Suggestions } & f & $\%$ & Rank \\
\hline 1 & Banks should extend crop loans for tenant farmers & 60 & 100.00 & I \\
\hline 2 & Tenancy contracts need to be monitored by the government & 58 & 96.67 & II \\
\hline 3 & Tenancy tenures should be at least for 3 to 5 years & 55 & 91.67 & III \\
\hline 4 & $\begin{array}{l}\text { Developmental departments should extend agricultural trainings for } \\
\text { tenant farmers on regular, season and time specific basis }\end{array}$ & 53 & 88.33 & IV \\
\hline $\mathbf{5}$ & Input subsidy should be extended for tenant farmers & 49 & 81.67 & V \\
\hline $\mathbf{6}$ & Government should monitor the land lease rents & 46 & 76.67 & VI \\
\hline 7 & All farmers should only go for written land lease agreements & 45 & 75.00 & VII \\
\hline $\mathbf{8}$ & Receipts should be given on payment of land lease rents & 42 & 70.00 & VIII \\
\hline 9 & Crop insurance should be extended for tenant farmers & 41 & 68.33 & IX \\
\hline 10 & Weather insurance should be extended for tenant farmers & 40 & 66.67 & X \\
\hline Note: Responses are inclusive & & & \\
\hline
\end{tabular}


It is evident from Table 2 that 61.67 per cent of the tenant farmers had medium level of adoption about chilli production technology whereas, 23.33 per cent and 15.00 per cent had high and low levels of adoption, respectively. The finding was in tune with Rath et al., (2007) and Singh et al., (2011).

\section{Problems faced by the tenant farmers in tenant farming}

An attempt was made to find out the problems encountered and perceived by the tenant farmers in tenant farming and ranks were given based on the percentage of respondents perceived a particular problem. The results are presented in Table 3. The problems were identified and ranked based on frequency and percentage.

It was evident from the Table 3. that, cent per cent of the tenant farmers perceived that 'land lease rents are hiked and more'; 'most of the land owners demand land leased rent before the commencement of the cropping season'; and 'lack of financial support from banks' (I rank) as most severe problem in tenancy farming; while 93.33 per cent perceived that 'it is difficult to pay the entire land lease rent in the form of cash'(II rank); and 'money lenders are main source of credit lending money at high interest rates' (II rank); 85.00 per cent perceived that 'tenancy tenures are mostly short term' (III rank); 80.00 per cent perceived that 'developmental departments do not offer agricultural trainings for tenant farmers' (IV rank); 73.33 per cent perceived that 'input subsidy is not applicable for tenant farmers' (V rank); 68.33 per cent perceived that 'no fixed land lease rents' (VI rank); 66.67 per cent perceived that 'no vouchers are given for payment of lease rents for the land' (VII rank); 60.00 per cent perceived that 'lease contracts are verbal and no written agreements are made' (VIII rank); 53.33 per cent perceived that 'crop insurance is not applicable for tenant farmers' (IX rank); and 43.33 per cent perceived that 'weather insurance is not applicable for tenant farmers' (X rank) as Problems in tenant farming.

The land lease rents are hiked and more. In majority of the cases, tenant farmers had to pay cent per cent of the land leased rent before the commencement of the cropping season on the demand of land owners. Due of the lack of financial support from banks, the tenant farmers had to approach money lenders for financial support for investment in farming. Money lenders lend money at high interest rates leading tenants into debts. Tenancy tenures are mostly short term, so tenant farmers cannot concentrate on land improvement practices. Tenures are short term probably to avoid land seizing related problems. Moreover, either governmental or non-governmental developmental organizations usually sponsor agricultural training programmes for owner farmers only. Input subsidies are also for owner farmers only and not for tenant farmers. The leased rents for a particular crop are not constant, probably due to difference in land physical properties. Hence lot of competition among the farmers interested in tenancy farming. Whoever bids a high lease rent, he or she becomes tenant of that land. Mostly the lease contracts are oral, rarely they are written and no vouchers are given when leased rents are paid. Hence, no guarantee about the lease, tenure and owner can throw the tenants out any time from the fields and no one can protest it. Schemes like crop insurance and weather insurances are available only for owner farmers and not for tenant farmers.

\section{Suggestions for tenant farmers to overcome the problems in tenant farming}

Based on the problems, the suggestions were drawn from the farmers to overcome them and presented in Table 4. Suggestions were 
identified and ranked based on frequency and percentage.

It was evident from Table 4 that cent per cent of the tenant farmers suggested that 'banks should extend crop loans for tenant farmers' (I rank); while 96.67 per cent perceived that 'tenancy contracts need to be monitored by the government' (II rank); 91.67 per cent recommended that 'tenancy tenures should be at least for 3 to 5years' (III rank); 88.33 per cent were in the view that 'developmental departments should extend agricultural trainings for tenant farmers on regular, season and time specific basis' (IV rank); 81.67 per cent opined that 'input subsidy should be extended for tenant farmers' (V rank); 76.67 per cent believes that 'government should monitor the land lease rents' (VI rank); 75.00 per cent stated that 'all farmers should only go for written land lease agreements' (VII rank); 70.00 per cent reported that 'receipts should be given on payment of land lease rents' (VIII rank); 68.33 per cent viewed that 'crop insurance should be extended for tenant farmers' (IX rank); and 66.67 per cent suggested that 'weather insurance should be extended for tenant farmers' (X rank) as solutions to solve the above mentioned problems of tenant farmers in tenant farming.

Government has brought tenancy reforms, but the implementation has not reached at farmer level. Moreover, government has already given permission to banks to implement crop loans for tenant farmers but banking sector as a whole is not taking a step ahead to implement it. There are certain loop holes in the tenancy forms, mainly the documentary proof of contract between the land owner and tenant farmer is absolutely missing in majority of the cases, only in a very meager proportion of the cases such documentary proofs exists. On the whole, such documentary evidences are very much required to implement any promotional schemes for instance, crop loans, insurances, etc for tenant farmers.

\section{References}

Devi, R.S., Gopal, S.P.V., Sailaja, V and Prasad, S.V. 2012. Problems encountered by Sugarcane farmers and suggestions to overcome the problems. Journal of Research ANGRAU. 40 (4): 140-141.

Rai, D.P and Singh, B. 2010. Extent of Knowledge and Constraints in Cotton Production Technology in Madhya Pradesh. Indian Research Journal of Extension Education. 10 (2): 78-80.

Rath, N.C., Lipidas, Mishra, S.K. and Lenka, S. 2007. Adoption of Upland rice technologies and its correlates. Oryza. 44 (4): 347-350.

Singh, P.K., Barman, K.K and Varshney, J.G. 2011. Adoption behaviour of vegetable growers towards improved technologies. Indian Research Journal of Extension Education. 11 (1): 62-65.

\section{How to cite this article:}

Kiranmayi, K. and Vijayabhinandana, B. 2018. Critical Analysis of Adoption Pattern and Problems of Chilli Growers in Tenant Farming. Int.J.Curr.Microbiol.App.Sci. 7(11): 22112218. doi: https://doi.org/10.20546/ijcmas.2018.711.247 